\title{
Effect of Integrated K Management on Productivity and Nutrient Use Efficiency of Maize-Wheat Cropping System
}

\author{
Sanjeev Kumar ${ }^{1 *}$, Shiva Dhar ${ }^{2}$, R.S. Yadav ${ }^{3}$, M. Chandrakala ${ }^{4}$, S.A. Kochewad ${ }^{5}$, \\ L.R. Meena ${ }^{6}$, L.K. Meena ${ }^{6}$, Magan Singh ${ }^{1}$ and Arpan Bhowmik ${ }^{7}$ \\ ${ }^{1}$ Agronomy Section, NDRI Karnal-132001, India \\ ${ }^{2}$ Division of Agronomy, IARI, New Delhi-110012, India \\ ${ }^{3}$ Indian Institute of Soil and Water Conservation, Regional Centre, Datia-475661, India \\ ${ }^{4}$ NBSS-LUP, Bangalore-560024, India \\ ${ }^{5}$ IVRI, Izatnagar, Uttar Pradesh - 243122, India \\ ${ }^{6}$ IIFSR, Modipuram, Meerut - 250 110, India \\ ${ }^{7}$ IASRI, New Delhi - 110 012, India \\ *Corresponding author
}

\section{Keyw o r d s \\ Farmyard manure, K dynamics, Muriate of Potash, Nutrient use efficiency, Productivity Article Info \\ Accepted: 08 July 2018 Available Online: 10 August 2018}

\section{A B S T R A C T}

A field experiment was conducted during the rainy (June - October) and winter (November - March) seasons for two years during 2010-2012 at research farm of ICAR - Indian Agricultural Research Institute, New Delhi, India. The experiment was laid out in a randomized block design consisting of seven treatments and three replication. Results revealed the integrated application of $90 \mathrm{~kg} \mathrm{~K} \mathrm{ha}^{-1}$ supplemented through muriate of potash (MOP)@60 kg K and farmyard manure (FYM) @ 30 kg K resulted in highest grain yield of $4.93 \mathrm{t} \mathrm{ha}^{-1}$ and biological yield of $11.71 \mathrm{t} \mathrm{ha}^{-1}$ in maize. Similarly, highest grain yield of $5.44 \mathrm{t} \mathrm{ha}^{-1}$ and biological yield of $14.03 \mathrm{t} \mathrm{ha}^{-1}$ were observed in treatment applied with integrated dose of $\mathrm{K} @ 90 \mathrm{~kg} \mathrm{~K} \mathrm{ha}^{-1}$ supplemented through MOP and FYM in wheat crop. The highest uptake of $\mathrm{K}$ was observed under treatment applied through $30 \mathrm{~kg} \mathrm{~K}$ through $\mathrm{MOP}+30 \mathrm{~kg} \mathrm{~K}$ through FYM in both cropping cycles. Nutrient use efficiency of $\mathrm{N}, \mathrm{P}$ and $\mathrm{K}$ increased by $\mathrm{K}$ application. In soil, decline was observed in different fractions of $\mathrm{K}$ irrespective of different applied $\mathrm{K}$ treatments. All the treatments where $\mathrm{K}$ was added showed a negative balance of $\mathrm{K}$ availability in soil. Application of $60 \mathrm{~kg} \mathrm{~K} \mathrm{ha}^{-1}$ through MOP in both the season showed minimum negative $\mathrm{K}$ balance $\left(-281.3 \mathrm{~kg} \mathrm{ha}^{-1}\right)$. Integrated $\mathrm{K}$ application@90 Kg K ha ${ }^{-1}$ resulted in highest exchangeable and nonexchangeable $\mathrm{K}$ in the soil for both seasons. To achieve a sustained yield level, nutrient use efficiency and soil fertility integrated $\mathrm{K}$ application @ $60 \mathrm{~kg} \mathrm{~K} \mathrm{ha}^{-1}$ for the rainy season in maize and a dose of $60 \mathrm{~kg} \mathrm{~K} \mathrm{ha}^{-1}$ through MOP alone in the winter season for wheat crop may be recommended. 


\section{Introduction}

Potassium $(\mathrm{K})$ is one of the major essential nutrients for growth and yield of crops. A large amount of $\mathrm{K}$ is absorbed from rhizospheric soil through roots and it plays crucial role in antagonistic and synergistic interaction with other essential nutrients of required for crops (Zhang et al., 2010). Timsina et al., (2010) observed that even with the recommended levels of nutrient application, there is continuous gap between nutrients removal to nutrient applied in soil under different cropping systems. Continuous intensive cropping, low $\mathrm{K}$ application and heavy mining of $\mathrm{K}$ results into declining in available $\mathrm{K}$ in soils under long-term fertilizer experiments (Sharma et al., 2014). In another finding, Kumar (2016) reported that when exchangeable $\mathrm{K}$ decreases in the soil pearl millet and wheat crop started extracting $\mathrm{K}$ from non-exchangeable $\mathrm{K}$ reserves in the soils. Globally, North America is one of the largest producer with a share of $49 \%$ of $\mathrm{K}$ fertilizers production followed by East Europe and Central Asia with a share of $39 \%$ by the end of 2018 (FAO, 2015). The K fertilizer demand is expected to reach 34.5 MT in 2018 which can be meet out by the total production of 51.4 million tonnes around the world. But, it might be uneconomical approach for farmers due to higher $\mathrm{K}$ fertilizer input index with low food output price index that will raise food insecurity problems in different parts of the world. Hence, there is pertinent need to find out some alternative source of K. Farmyard Manure (FYM) may be a better option to overcome such problems which is cheaper, easily available, improves soil health and capable to solubilize native $\mathrm{K}$ in soil. FYM accelerates mineral weathering and aids in solubilization of plant nutrients from otherwise insoluble minerals. It also provides slowly available carbon and energy source to support a large diverse, metabolically active microbial community which helps solubilization and availability of nutrients to crop plants (Paul, 2014). Keeping in view the above facts, the present study was conducted to investigate the effect of integrated $\mathrm{K}$ management on productivity and nutrient use efficiency under maize - wheat cropping system in an inceptisol.

\section{Materials and Methods}

\section{Experimental site}

Field experiments were conducted during rainy (kharif) and winter (rabi) seasons of 2010-11 and 2011-12 at Research Farm of Indian Agricultural Research Institute, New Delhi situated in north western India (28.35 N, 77.12 ' E) and at $228.6 \mathrm{~m}$ above $\mathrm{msl}$.

\section{Treatments details}

The experiment was carried out in randomized block design with three replication and seven $\mathrm{K}$ management treatments were applied to both maize (M) in rainy season and wheat (W) in winter season at fixed site. $\mathrm{K}$ management treatments consisted of: $\mathrm{T}_{1}$ (control, no $\mathrm{K}$ applied to both maize \& wheat), $\mathrm{T}_{2}(30 \mathrm{~kg} \mathrm{~K}$ $\mathrm{ha}^{-1}$ through MOP $+30 \mathrm{~kg} \mathrm{~K} \mathrm{ha}{ }^{-1}$ through FYM to maize and $60 \mathrm{~kg} \mathrm{ha}^{-1} \mathrm{~K}$ through MOP to wheat), $\mathrm{T}_{3}\left(60 \mathrm{~kg} \mathrm{~K} \mathrm{ha}^{-1}\right.$ through MOP +30 $\mathrm{kg} \mathrm{K} \mathrm{ha}{ }^{-1}$ through FYM to maize and no application of $\mathrm{K}$ to wheat), $\mathrm{T}_{4}\left(30 \mathrm{~kg} \mathrm{~K} \mathrm{ha}^{-1}\right.$ through MOP+30 kg K ha ${ }^{-1}$ through FYM to maize and no application of $\mathrm{K}$ to wheat), $\mathrm{T}_{5}$ $\left(60 \mathrm{~kg} \mathrm{~K} \mathrm{ha}^{-1}\right.$ through MOP to maize and $30 \mathrm{~kg}$ $\mathrm{ha}^{-1} \mathrm{~K}$ through $\mathrm{MOP}+30 \mathrm{~kg} \mathrm{~K} \mathrm{ha}^{-1}$ through FYM to wheat), $\mathrm{T}_{6}\left(60 \mathrm{~kg} \mathrm{~K} \mathrm{ha}^{-1}\right.$ through MOP to maize and $60 \mathrm{~kg} \mathrm{ha}^{-1} \mathrm{~K}$ through MOP to wheat) and $T_{7}$ (no application of $K$ to maize and $60 \mathrm{~kg} \mathrm{~K} \mathrm{ha}^{-1}$ through MOP+ $30 \mathrm{~kg} \mathrm{~K} \mathrm{ha}^{-1}$ through FYM to wheat). Recommended doses of $150 \mathrm{~kg} \mathrm{~N} / \mathrm{ha}$ and $26 \mathrm{~kg} \mathrm{P} \mathrm{ha}{ }^{-1}$ were applied to maize through urea and diammonium phosphate (DAP), respectively. The full dose of $\mathrm{P}, \mathrm{K}$ and $50 \mathrm{~kg} \mathrm{~N} / \mathrm{ha}$ were given as basal 
dose and remaining $100 \mathrm{~kg} \mathrm{~N} \mathrm{ha}^{-1}$ was given in two splits of $50 \mathrm{~kg} \mathrm{~N} / \mathrm{ha}$ each at 30 and 60 days after sowing (DAS). Muriate of potash (MOP) and farmyard manure (FYM) were used as sources of $\mathrm{K}$ and applied as per treatments. Wheat was given $120 \mathrm{~kg} \mathrm{~N}^{-1}$ through urea and $26 \mathrm{~kg} \mathrm{P} \mathrm{ha}^{-1}$ through DAP. During 2010 and 2011, the amount of N, P and K in FYM applied was 5 and $6 \mathrm{~g} \mathrm{~N} / \mathrm{kg}, 4$ and $4 \mathrm{~g} \mathrm{P} \mathrm{kg}^{-1}$ and 5 and $4 \mathrm{~g} \mathrm{~K} \mathrm{~kg}^{-1}$ respectively. The amount of $\mathrm{N}, \mathrm{P}$ and $\mathrm{K}$ applied through urea, DAP and FYM were adjusted in all the treatments to maintain the required nutrient combinations. All the nutrients were given by broadcast and thoroughly mixed in the soil before sowing. The variety chosen were "PEHM 2" for maize and "HD 2967" for wheat. The spacing adopted was $60 \mathrm{~cm} \mathrm{x} 20$ for maize $\mathrm{cm}$ and $22.5 \mathrm{~cm}$ row spacing for wheat. The seed rate used for maize was $20 \mathrm{~kg} \mathrm{ha}^{-1}$ and wheat 100 $\mathrm{kg} \mathrm{ha}^{-1}$.

\section{Yield observation recording}

At maturity, plants of maize and wheat were harvested manually from centre of each plot in an area of $4.8 \mathrm{~m}^{2}$ and $4.5 \mathrm{~m}^{2}$. After separation of stems and grains dry weights were determined. The aboveground biomass per hectare was calculated based on the dried plant samples. The yield per hectare was calculated based on the dried plant samples.

\section{Soil-plant sampling and K estimation}

Soil samples were collected and processed as per standard procedures. The $\mathrm{K}$ was determined in plants by flame photometer (Prasad et al., 2006). Water soluble $\mathrm{K}$ and non-exchangeable $\mathrm{K}$ was extracted using procedure described by Page et al., (1982). Exchangeable $\mathrm{K}$ was extracted by procedure given by Hanway and Heidel (1952).

\section{K balance estimation}

Annual apparent $\mathrm{K}$ balances were estimated for all the treatments by using different inputs and outputs measured during the present experiments. Average crop yields were considered for apparent balance estimation.

$\mathrm{K}$ balance $=\sum$ (fertilizer $\mathrm{K}$, manure $\mathrm{K}$, rain $\mathrm{K}$, irrigation $\mathrm{K})-\sum(\mathrm{K}$ uptake, Losses of $\mathrm{K})$

Among inputs, $\mathrm{K}$ contents in mineral fertilizer, organic manure and irrigation water were measured in the present study.

The $\mathrm{K}$ contribution of $5 \mathrm{~kg} \mathrm{ha}^{-1} \mathrm{yr}^{-1}$ with rainfall water was estimated from the water collected in raingauge analyzed by the protocol given by Standford and English (1949). Leaching loss of K was taken to be $150 \mathrm{~g} \mathrm{~kg}^{-1} \mathrm{~K}$ input (Smaling and Fresco, 1993).

\section{Nutrient use efficiency}

Partial factor productivity (PFP) was obtained to indicate the nutrient use efficiency of the applied $\mathrm{N}, \mathrm{P}$, and $\mathrm{K}$ and calculated as grain yield $(\mathrm{kg})$ per unit $(\mathrm{kg})$ of $\mathrm{N}, \mathrm{P}$ and $\mathrm{K}$ applied. In addition, the $\mathrm{K}$ use efficiency was also assessed by:

(i) agronomic efficiency (AEK), calculated as the increase in grain yield from applied nutrients relative to the control treatment in the same production practice ( $\mathrm{kg}$ grain $\mathrm{kg}^{-1} \mathrm{~K}$ applied via fertilizer); (ii) apparent recovery efficiency (REK), defined as the amount of added $K$ that was recovered in the aboveground plant biomass at the end of the cropping season (Dobermann, 2005) and calculated as

PFP $=($ Grain Yield/Nutrient applied $) \ldots \ldots . .(1)$

AEK $=\quad($ Grain Yield in fertilized plot Grain yield in control plot)/Amount of fertilizer applied.

REK $=\quad(\mathrm{K}$ uptake in fertilized plot $-\mathrm{K}$ uptake in control plot)/ $\mathrm{K}$ applied... 


\section{Statistical Analysis}

The standard error of mean (SEm \pm ), least significant difference (LSD) at 0.05 probability were worked out for each parameter of the study by using Analysis of Variance (ANOVA) technique for randomized block design in both maize and wheat crop as per standard procedure (Gomez and Gomez, 1984).

\section{Results and Discussion}

\section{Yield of maize and wheat}

A significant positive response of grain, stover and biological yield was observed in all the treatments applied with $\mathrm{K}$ and found significantly superior over treatments without $\mathrm{K}$ application (Table 1). Application of $60 \mathrm{~kg}$ $\mathrm{K} \mathrm{ha}^{-1}$ through MOP $+30 \mathrm{~kg} \mathrm{~K} \mathrm{ha}^{-1}$ through FYM to maize and no $K$ to wheat $\left(T_{3}\right)$ recorded highest grain $\left(4.93 \mathrm{Mg} \mathrm{ha}^{-1}\right)$, stover $\left(6.78 \mathrm{Mg} \mathrm{ha}^{-1}\right)$ and biological yield $(11.71 \mathrm{Mg}$ $\mathrm{ha}^{-1}$ ) of maize which was closely followed by application of $30 \mathrm{~kg} \mathrm{~K} \mathrm{ha}^{-1}$ through MOP + 30 $\mathrm{kg} \mathrm{K} \mathrm{ha}{ }^{-1}$ through FYM to maize and $60 \mathrm{~kg}$ $\mathrm{ha}^{-1} \mathrm{~K}$ through MOP to wheat $\left(\mathrm{T}_{2}\right)$ and application of $30 \mathrm{~kg} \mathrm{~K} \mathrm{ha}^{-1}$ through $\mathrm{MOP}+30$ $\mathrm{kg} \mathrm{K} \mathrm{ha}^{-1}$ through FYM to maize and no $\mathrm{K}$ to wheat $\left(\mathrm{T}_{4}\right)$. Whereas, application of $60 \mathrm{~kg} \mathrm{~K}$ $\mathrm{ha}^{-1}$ through MOP+30 kg K ha ${ }^{-1}$ through FYM to wheat and no $\mathrm{K}$ to preceding maize $\left(\mathrm{T}_{7}\right)$ recorded highest grain (5.44 Mg ha ${ }^{-1}$ ) and biological yield (14.03 $\mathrm{Mg} \mathrm{ha}^{-1}$ ) of wheat which was significantly higher than other $\mathrm{K}$ application treatments. No significant difference was observed in straw yields of wheat. The improvement in yield was due to applied $\mathrm{K}$ which is vital to many plant processes including photosynthesis, translocation of photosynthates, protein synthesis, activation of plant enzymes etc (IPNI, 1998). Kumar et al., (2014) reported that integrated use of $\mathrm{K}$ (FYM and MOP) recorded significantly higher yield compared to $100 \% \mathrm{NP}$ and $100 \%$ NPK fertilizers due to availability of different macro and micro nutrients in available form through biological decomposition. Similarly, Zhang et al., (2011) found that inorganic NPK fertilization significantly increased grain yields of wheat (21\%) and maize (16-72\%) compared to inorganic $\mathrm{N}$ and $\mathrm{P}$ fertilization indicating the importance of application of K. Similar, results were reported in wheat crop by Polara et al., (2009) and Wani et al., (2014).

\section{$\mathrm{K}$ uptake and balance}

Application of $\mathrm{K}$ significantly affected $\mathrm{K}$ uptake in grain, stover/straw and their total uptake during both the cropping cycle (Table 2 ). The highest uptake of $K$ was observed with application of $30 \mathrm{~kg} \mathrm{~K}^{-1}$ through $\mathrm{MOP}+30$ $\mathrm{kg} \mathrm{K} \mathrm{ha}{ }^{-1}$ through FYM to maize and $60 \mathrm{~kg}$ $\mathrm{ha}^{-1} \mathrm{~K}$ through MOP to wheat $\left(\mathrm{T}_{2}\right)$ closely followed by application of $60 \mathrm{~kg} \mathrm{~K} \mathrm{ha}{ }^{-1}$ through MOP+30 kg K ha ${ }^{-1}$ through FYM to maize and no $\mathrm{K}$ to wheat $\left(\mathrm{T}_{3}\right)$ during both the cropping cycles. The least uptake of $\mathrm{K}$ was observed in treatment $T_{1}$, where no $K$ was applied during both the cropping cycles. This higher uptake in treatment applied was recorded due to higher concentration of $\mathrm{K}$ in the grain and stover/straw and increased yields due under $\mathrm{K}$ fertilized treatments, which resulted into higher amount of $\mathrm{K}$ uptake from the soil. Zafar et al., (2016) reported that increase in $\mathrm{K}$ concentration and uptake in wheat grains and straw increased significantly with application of $\mathrm{K}$. Uptake of $\mathrm{K}$ in under treatment with no $\mathrm{K}$ application may be attributed to interactive effect of $\mathrm{N}$ and $\mathrm{K}$. The greater $\mathrm{K}$ uptake was recorded when $\mathrm{K}$ was supplemented through FYM along to $\mathrm{K}$ added through MOP in comparison with $\mathrm{K}$ application through MOP alone (Zhang et al., 2011).

After completion of two cropping cycles of maize -wheat cropping system, all the 
integrated $\mathrm{K}$ application treatments showed negative balance (Table 3). The highest negative $\mathrm{K}$ balance $\left(-382.3 \mathrm{~kg} \mathrm{ha}^{-1}\right)$ was observed with the application of $60 \mathrm{~kg} \mathrm{~K} \mathrm{ha}^{-1}$ through MOP+30 kg K ha ${ }^{-1}$ through FYM to maize and no $\mathrm{K}$ to wheat $\left(\mathrm{T}_{3}\right)$ followed by $\mathrm{T}_{4}$. The least $\mathrm{K}$ negative balance was observed in treatment $\mathrm{T}_{6}\left(-281.3 \mathrm{~kg} \mathrm{ha}^{-1}\right)$. The extra $\mathrm{K}$ uptake under the NP fertilized treatment was probably either from the deeper subsoil or from the release of non-exchangeable $\mathrm{K}$, which was one of the important $\mathrm{K}$ source for plants under the treatment applied with no $\mathrm{K}$ (Markgraf et al., 2012; Zhao et al., 2014).

The highest negative balance was observed in treatments applied with FYM along with MOP which was due to increased yield and higher uptake by the crop from applied $\mathrm{K}$ as well as from soil (Paramasivan et al., 2012; Mazumdar et al., 2014). The negative apparent $\mathrm{K}$ balance under treatment applied with $\mathrm{K}$ through MOP were probably related to higher $\mathrm{K}$ fixation in the clay interlayer when additional amount of $\mathrm{K}$ was present, this resulted into decreased availability of $\mathrm{K}$ for uptake by the crops (Qiu et al., 2014).

\section{K dynamics}

During both the rainy and winter season all the $\mathrm{K}$ forms showed a decreasing trend with different magnitude irrespective of treatments applied (Table 4). In rainy season, highest water soluble $\mathrm{K}$ ( $17.03 \mathrm{mg} \mathrm{kg}^{-1}$ ), exchangeable $\mathrm{K}\left(94.18 \mathrm{mg} \mathrm{kg}^{-1}\right)$ and non exchangeable $\mathrm{K}$ (787.45 mg kg${ }^{-1}$ ) was recorded in treatment $T_{3}$ which was significantly superior over treatment $\mathrm{T}_{1}$.

In winter season, highest water soluble $\mathrm{K}$ was observed in treatment $T_{2}$ whereas highest exchangeable $\mathrm{K}\left(90.87 \mathrm{mg} \mathrm{kg}^{-1}\right)$ and non exchangeable $\mathrm{K} \quad\left(737.92 \mathrm{mg} \mathrm{kg}^{-1}\right)$ was observed in treatment $T_{3}$. The decrease in different forms of $\mathrm{K}$ was attributed to heavy withdrawal of $\mathrm{K}$ by crop plants from the soil compared to the K applied to soil. Setia et al., (2009) reported that under maize - wheat rotation, when only $\mathrm{N}$ and $\mathrm{P}$ were applied, available $\mathrm{K}$ [ammonium acetate $\left(\mathrm{NH}_{4} \mathrm{OAC}\right)-$ extractable $\mathrm{K}$ ] decreased significantly over time. Lack of $\mathrm{K}$ application resulted into decrease in water soluble and exchangeable $\mathrm{K}$. Similar findings were also reported by Sattari (2014).

\section{Nutrients use efficiency}

A significant positive response was observed in PFP of $\mathrm{N}$ and $\mathrm{P}$ for both maize and wheat crop with $\mathrm{K}$ application (Table 5). In maize, highest PFP of N (32.9) and P (189.6) was observed with application of $60 \mathrm{~kg} \mathrm{~K} \mathrm{ha}{ }^{-1}$ through MOP+30 $\mathrm{kg} \mathrm{K} \mathrm{ha}^{-1}$ through FYM to maize and no $K$ to wheat $\left(T_{3}\right)$, which was found significantly superior over $T_{1}$ treatment. Highest PFP (73.2), agronomic efficiency (36.8) and crop recovery efficiency (1.23) of K was also observed in $T_{3}$ treatment. In wheat, highest PFP of N (45.3) and P (207.1) was also observed in $\mathrm{T}_{3}$ treatment, which was found significantly higher than $T_{1}$ treatment. The highest PFP (85.1), agronomic efficiency (21.0) and crop recovery efficiency (0.82) of K was observed in $T_{5}$ treatment. Increasing the input of $\mathrm{K}$ nutrient is a practical way to balance the $\mathrm{N} / \mathrm{P} / \mathrm{K}$ ratio to improve the nutrient use efficiency (Yang et al., 2014).

The PFP of $\mathrm{N}$ increased with increasing $\mathrm{K}$ input under the same production practice, which indicates positive interactions between $\mathrm{N}$ and K. Similarly the PFP of P was increased in the treatments applied with higher amount of $\mathrm{K}$ which leads to higher uptake of $\mathrm{K}$ due to synergistic effect of $\mathrm{K}$ with $\mathrm{P}$ ion. $\mathrm{K}$ is an important element which plays major role in translocation of different ions in plant part from soil which leads to improvement in various nutrient use efficiencies (Niu et al., 2011). 
Table.1 Effect of integrated $\mathrm{K}$ fertilization on yield $\left(\mathrm{Mg} \mathrm{ha}^{-1}\right)$ of maize and wheat in maize - wheat cropping system (mean of two years)

\begin{tabular}{|c|c|c|c|c|c|c|c|}
\hline \multirow{2}{*}{ Treatment } & \multicolumn{3}{|c|}{ Maize } & \multicolumn{3}{c|}{ Wheat } \\
\cline { 2 - 7 } & Grain & Stover & Biological & Grain & Straw & Biological \\
\hline $\mathbf{T}_{\mathbf{1}}$ & 2.46 & 4.87 & 7.33 & 3.84 & 7.44 & 11.28 \\
\hline $\mathbf{T}_{\mathbf{2}}$ & 4.29 & 6.33 & 10.62 & 5.00 & 7.93 & 12.33 \\
\hline $\mathbf{T}_{\mathbf{3}}$ & 4.93 & 6.78 & 11.71 & 4.27 & 7.91 & 12.05 \\
\hline $\mathbf{T}_{\mathbf{4}}$ & 4.27 & 6.23 & 10.50 & 4.14 & 8.46 & 13.57 \\
\hline $\mathbf{T}_{\mathbf{5}}$ & 3.64 & 5.83 & 9.47 & 5.11 & 8.09 & 12.93 \\
\hline $\mathbf{T}_{\mathbf{6}}$ & 3.61 & 5.82 & 9.43 & 4.84 & 8.59 & 14.03 \\
\hline $\mathbf{T}_{\mathbf{7}}$ & 2.71 & 5.15 & 7.86 & 5.44 & NS & 1.22 \\
\hline
\end{tabular}

Table.2 K uptake $\left(\mathrm{kg} \mathrm{ha}^{-1}\right)$ as influenced by $\mathrm{K}$ application in maize - wheat cropping system

\begin{tabular}{|c|c|c|c|c|c|c|}
\hline \multirow[t]{2}{*}{ Treatment } & \multicolumn{3}{|c|}{ Cropping Cycle I (2010-11) } & \multicolumn{3}{|c|}{ Cropping Cycle II (2011-12) } \\
\hline & Grain & Stover/Straw & Total & Grain & Stover/Straw & Total \\
\hline $\mathbf{T}_{1}$ & 12.88 & 73.79 & 86.67 & 13.97 & 81.02 & 94.98 \\
\hline $\mathbf{T}_{2}$ & 22.82 & 109.96 & 132.78 & 28.57 & 122.24 & 150.81 \\
\hline $\mathbf{T}_{3}$ & 22.69 & 109.44 & 132.12 & 26.89 & 119.25 & 146.14 \\
\hline $\mathbf{T}_{4}$ & 19.15 & 97.48 & 116.63 & 22.48 & 107.95 & 130.43 \\
\hline $\mathbf{T}_{5}$ & 21.09 & 99.70 & 120.79 & 27.22 & 120.19 & 147.41 \\
\hline $\mathbf{T}_{6}$ & 19.85 & 97.45 & 117.30 & 25.25 & 113.04 & 138.29 \\
\hline $\mathbf{T}_{7}$ & 19.90 & 96.10 & 116.00 & 23.51 & 115.34 & 138.85 \\
\hline LSD $(P \leq 0.05)$ & 2.19 & 13.97 & 15.37 & 3.32 & 14.23 & 14.61 \\
\hline
\end{tabular}


Table.3 Apparent $\mathrm{K}$ balance $\left(\mathrm{kg} \mathrm{ha}^{-1}\right)$ as influenced by $\mathrm{K}$ application in maize - wheat cropping system (over two years)

\begin{tabular}{|c|c|c|l|l|l|l|l|}
\hline Treatment & \multicolumn{3}{|c|}{ Input } & \multicolumn{3}{c|}{ Output } & Balance \\
\cline { 2 - 8 } & Manure/fertili & Irrigatio & Rain & Grain & Stover/ & Leaching & \\
\hline $\mathbf{T}_{\mathbf{1}}$ & 0 & 20 & 5.0 & 53.6 & 309.6 & 4.2 & -345.7 \\
\hline $\mathbf{T}_{\mathbf{2}}$ & 240 & 20 & 5.0 & 102.8 & 464.3 & 40.7 & -336.3 \\
\hline $\mathbf{T}_{\mathbf{3}}$ & 180 & 20 & 5.0 & 99.2 & 457.4 & 30.7 & -382.3 \\
\hline $\mathbf{T}_{\mathbf{4}}$ & 120 & 20 & 5.0 & 83.2 & 410.8 & 21.6 & -371.6 \\
\hline $\mathbf{T}_{\mathbf{5}}$ & 240 & 20 & 5.0 & 96.7 & 439.8 & 41.0 & -304.2 \\
\hline $\mathbf{T}_{\mathbf{6}}$ & 240 & 20 & 5.0 & 90.2 & 421.0 & 40.6 & -281.3 \\
\hline $\mathbf{T}_{\mathbf{7}}$ & 180 & 20 & 5.0 & 86.8 & 422.9 & 32.4 & -326.3 \\
\hline
\end{tabular}

Table.4 Effect of $\mathrm{K}$ fertilization on $\mathrm{K}$ dynamics $\left(\mathrm{mg} \mathrm{kg}^{-1}\right)$ in soil under maize- wheat cropping system (means of two years)

\begin{tabular}{|c|c|c|c|c|c|c|}
\hline \multirow{2}{*}{ Treatment } & \multicolumn{3}{|c|}{ Rainy Season } & \multicolumn{3}{c|}{ Winter Season } \\
\cline { 2 - 7 } & Water soluble K & $\begin{array}{c}\text { Exchangeable } \\
\text { K }\end{array}$ & $\begin{array}{c}\text { Non-Exchangeable } \\
\text { K }\end{array}$ & $\begin{array}{c}\text { Water soluble } \\
\text { K }\end{array}$ & $\begin{array}{c}\text { Exchangeable K } \\
\text { Exchangeable K }\end{array}$ \\
\hline $\mathbf{T}_{\mathbf{1}}$ & $13.72^{\mathrm{d}}$ & $74.53^{\mathrm{d}}$ & $704.00^{\mathrm{b}}$ & $11.82^{\mathrm{e}}$ & $65.45^{\mathrm{e}}$ & $650.18^{\mathrm{b}}$ \\
\hline $\mathbf{T}_{\mathbf{2}}$ & $16.75^{\mathrm{ab}}$ & $90.20^{\mathrm{a}}$ & $773.27^{\mathrm{a}}$ & $15.83^{\mathrm{a}}$ & $85.80^{\mathrm{ab}}$ & $730.95^{\mathrm{a}}$ \\
\hline $\mathbf{T}_{\mathbf{3}}$ & $17.03^{\mathrm{a}}$ & $94.18^{\mathrm{a}}$ & $787.45^{\mathrm{a}}$ & $15.23^{\mathrm{ab}}$ & $90.87^{\mathrm{a}}$ & $737.92^{\mathrm{a}}$ \\
\hline $\mathbf{T}_{\mathbf{4}}$ & $16.53^{\mathrm{ab}}$ & $89.00^{\mathrm{ab}}$ & $770.92^{\mathrm{ab}}$ & $14.82^{\mathrm{bc}}$ & $83.35^{\mathrm{bc}}$ & $719.28^{\mathrm{a}}$ \\
\hline $\mathbf{T}_{\mathbf{5}}$ & $15.90^{\mathrm{bc}}$ & $84.15^{\mathrm{bc}}$ & $762.05^{\mathrm{ab}}$ & $15.17^{\mathrm{b}}$ & $80.80^{\mathrm{bc}}$ & $719.20^{\mathrm{a}}$ \\
\hline $\mathbf{T}_{\mathbf{6}}$ & $15.58^{\mathrm{c}}$ & $82.83^{\mathrm{c}}$ & $761.33^{\mathrm{ab}}$ & $14.25^{\mathrm{c}}$ & $78.33^{\mathrm{cd}}$ & $710.45^{\mathrm{ab}}$ \\
\hline $\mathbf{T}_{\mathbf{7}}$ & $14.32^{\mathrm{d}}$ & $78.88^{\mathrm{cd}}$ & $724.13^{\mathrm{ab}}$ & $13.52^{\mathrm{d}}$ & $75.18^{\mathrm{d}}$ & $687.22^{\mathrm{ab}}$ \\
\hline
\end{tabular}


Table.5 Effect of K fertilization on nutrient use efficiency in maize- wheat cropping system (means of two years)

\begin{tabular}{|c|c|c|c|c|c|c|c|c|c|c|}
\hline \multirow[t]{2}{*}{ Treatment } & \multicolumn{5}{|c|}{ Maize } & \multicolumn{5}{|c|}{ Wheat } \\
\hline & PFPN & PFPP & PFPK & $\mathrm{AE} \mathrm{K}$ & CRE K & PFPN & PFPP & PFPK & AE K & CRE K \\
\hline $\mathbf{T}_{1}$ & 16.4 & 94.8 & - & - & - & 32.0 & 146.2 & - & - & - \\
\hline $\mathbf{T}_{2}$ & 28.6 & 164.9 & 71.4 & 30.4 & 0.98 & 41.6 & 190.0 & 83.3 & 19.2 & 0.72 \\
\hline $\mathbf{T}_{\mathbf{3}}$ & 32.9 & 189.6 & 73.2 & 36.8 & 1.23 & 35.6 & 162.4 & - & - & - \\
\hline $\mathbf{T}_{4}$ & 28.5 & 164.2 & 71.1 & 30.1 & 0.92 & 34.5 & 157.6 & - & - & - \\
\hline $\mathbf{T}_{5}$ & 24.3 & 140.1 & 60.7 & 19.7 & 0.62 & 42.6 & 194.3 & 85.1 & 21.0 & 0.82 \\
\hline $\mathbf{T}_{6}$ & 24.1 & 139.0 & 60.2 & 19.2 & 0.62 & 40.4 & 184.9 & 80.7 & 13.8 & 0.62 \\
\hline $\mathbf{T}_{7}$ & 18.0 & 104.1 & - & - & - & 45.3 & 207.1 & 60.4 & 13.7 & 0.72 \\
\hline LSD $(P \leq 0.05)$ & 2.83 & 16.2 & 13.1 & 8.4 & 0.30 & 3.58 & 17.49 & 4.8 & 5.6 & 0.14 \\
\hline
\end{tabular}


It is concluded that the study showed integrated application of $\mathrm{K}$ brought significant improvement in yield of both maize and wheat crops in a cropping cycle compared to sole source of $\mathrm{K}$ application. Inclusion of FYM as a source of $\mathrm{K}$ also results in increased use efficiency of $\mathrm{K}$. It also enhanced the use efficiency of $\mathrm{N}$ and $\mathrm{P}$. To achieve a sustained yield levels, nutrient use efficiency and soil fertility in a maize - wheat cropping cycle, it can be recommended that application of $60 \mathrm{~kg}$ $\mathrm{K} \mathrm{ha}^{-1}$ by integration of $30 \mathrm{~kg} \mathrm{~K}$ through MOP and $30 \mathrm{Kg} \mathrm{K}$ through FYM to maize and 60 $\mathrm{kg} \mathrm{K} \mathrm{ha}{ }^{-1}$ through MOP to wheat crop.

\section{Acknowledgements}

We are thankful to Indian Council of Agricultural Research and Indian Agricultural Research Institute for all supports including financial support to conduct this study.

\section{References}

Dobermann, A.R. 2005. Nitrogen use efficiency-state of the art. In: IFA international workshop on enhancedefficiency fertilizers, Frankfurt M., 28$30 \quad$ June 2005. doi:10.2135/cropsci2016.08.0648

FAO.2015. Current world fertilizer trends and outlook to 2018. Food and Agriculture Organisation, Rome.

Gomez, A.K. and Gomez, A. A.1984. Statistical procedures for agricultural research. John Wiley and Sons, New York.

Hanway, J.J. and Heidel, H.1952. Soil analysis methods as used in Iowa State College, Soil Testing Laboratory. Iowa Agriculture 54:1-31.

IPNI.1998. Functions of potassium in plants. Better Crops 82: 4-5.

Kumar, M.2016. Potassium Fractions in Soils of Long-term Fertilizer Experiment of Pearl-millet-Mustard Cropping sequence (Master dissertation, RVSKVV, Gwalior (MP).
Kumar, S., Shiva Dhar, Kumar, D., Kumar, B., Meena, R.L. and Hariom.2014.Bio fortification of crop residues for animal feeding in maize-wheat cropping system through integrated potassium management. Range Management Agroforestry 35: 220-226.

Markgraf, W., Watts, C. W., Whalley, W. R., Hrkac, T., and Horn, R.2012. Influence of organic matter on rheological properties of soil. Applied Clay Science 64: 25-33.

Niu, J. F., Zhang, W.F., Chen, X. P., Li, C.J., Zhang, F. S., Jiang, L.H., Liu, Z. H., Xiao, K., Assaraf, M., and Imas, P.2011. Potassium fertilization on maize under different production practices in the North China Plain. Agronomy Journal 103: 822-829.

Page, A. L., Miller, R. H. and Keeney, D. R. 1982. Methods of soil analysis. Part 2. Chemical and microbiological properties, 2nd edn. Agronomy, 9 ASA, SSSA, Madison, WI, p 1159.

Paul, E. A. 2014. Soil microbiology, ecology and biochemistry. Academic press.

Polara, K., Sardhara, R., Parmar, K., Babariya, N. and Patel, K.2009. Effect of potassium on inflow rate of $\mathrm{N}, \mathrm{P}, \mathrm{K}, \mathrm{Ca}$, $\mathrm{S}, \mathrm{Fe}, \mathrm{Zn}$ and $\mathrm{Mn}$ at various growth stages of wheat Asian Journal Soil Science 4:228-235.

Prasad, R., Shivay, Y. S., Kumar, D. and Sharma, S. N. 2006. Learning by doing exercise in soil fertility (A practical manual for soil fertility), Division of Agronomy, Indian Agricultural Research Institute, New Delhi, p8-38.

Qiu, S., Xie, J., Zhao, S., Xu, X., Hou, Y., Wang, X., Zhou, W., He, P., Johnston, A. M., Christie, P. and Jin, J. 2014. Long-term effects of potassium fertilization on yield, efficiency, and soil fertility status in a rain-fed maize system in northeast China. Field Crops Research 163:1-9.

Sattari, S. Z., Van Ittersum, M. K., Bouwman, A. F., Smith, A. L. and Janssen, B. H. 2014. Crop yield response to soil 
fertility and $\mathrm{N}, \mathrm{P}, \mathrm{K}$ inputs in different environments: testing and improving the QUEFTS model. Field Crops Research 157:35-46.

Setia, R., Sharma, K. N., Marschner, P. and Singh, H. 2009. Changes in Nitrogen, Phosphorus, and Potassium in a LongTerm Continuous Maize-Wheat Cropping System in India. Communication Soil Science and Plant Analysis 40:3348-3366.

Sharma, U., Paliyal, S. S., Sharma, S. P. and Sharma, G. D. 2014: Effects of continuous use of chemical fertilizers and manure on soil fertility and productivity of maize-wheat under rainfed conditions of the western Himalayas. Communication Soil Science and Plant Analysis 45: 2647-2659. DOI: 10.1080/00103624.2014.941854

Smaling, E.M.A. and Fresco, L.O.1993. A decision support model for monitoring nutrient balances under agricultural land use- nutmon. Geoderma 60:235-256.

Standford, S. and English, L.1949. Use of flame photometer in rapid soil tests for $\mathrm{K}$ and Ca. Agronomy Journal 4:446-447.

Timsina, J., Jat, M.L. and Majumdar, K.2010. Rice-maize systems of South Asia: current status, future prospects and research priorities for nutrient management. Plant Soil 335:65-82.

Wani, J. A., Malik, M.A., Dar, M. A., Akhter, F. and Raina, S. K. 2014. Impact of method of application and concentration of potassium on yield of wheat. Journal Environmental Biology 35:623.

Yang, X..Y, Sun, B.H. and Zhang, S.L. 2014. Trends of yield and soil fertility in a long-term wheat-maize system. Journal of Integrated Agriculture 13:402-414.

Zafar, S., Ashraf, M. Y., Anwar, S., Ali, Q. and Noman, A. 2016. Yield enhancement in wheat by soil and foliar fertilization of $\mathrm{K}$ and $\mathrm{Zn}$ under saline environment. Soil Environment 35:46-55.

Zhang, F., Niu, J., Zhang, W., Chen, X., Li, C., Yuan, L., and Xie, J.2010. Potassium nutrition of crops under varied regimes of nitrogen supply. Plant Soil, 335: 2124. https://doi.org/10.1007/s11104-0100323-4

Zhang, H. M., Yang, X. Y., He, X. H., Xu, M. G., Huang, S. M., Liu, H. and Wang, B. R. 2011. Effect of long term potassium fertilization on crop yield and potassium efficiency and balance under wheatmaize rotation in China. Pedosphere. 21, 154-163.

Zhao, S., He, P., Qiu, S., Jia, L., Liu, M., Jin, J. and Johnston, A. M. 2014. Long-term effects of potassium fertilization and straw return on soil potassium levels and crop yields in north-central China. Field Crops Research 169:116-122.

\section{How to cite this article:}

Sanjeev Kumar, Shiva Dhar, Yadav, R.S., Chandrakala, M., Kochewad, S.A., Meena, L.R., Meena, L.K., Magan Singh and Arpan Bhowmik. 2018. Effect of Integrated K Management on Productivity and Nutrient Use Efficiency of Maize-Wheat Cropping System. Int.J.Curr.Microbiol.App.Sci. 7(08): 1052-1061. doi: https://doi.org/10.20546/ijcmas.2018.708.119 